\title{
DORMANCY OVERCOMING IN Bowdichia virgilioides Kunth SEEDS
}

\author{
Claudio Brito Coêlho', Fernanda Vanilly de Lira Pauloº, Bruno Leal Viana ${ }^{2}$ \\ ${ }^{1}$ Graduando em Engenharia Florestal, Universidade Federal Rural de Pernambuco (UFRPE). Dom Manuel de Medeiros, s/n - Dois \\ Irmãos - Recife - PE - CEP 52171-900 \\ ${ }^{2}$ Analista de Desenvolvimento Ambiental, Jardim Botânico do Recife (JBR). BR 232, km 7,5 - Curado - CEP 50791-540 \\ Autor para correspondência: Bruno Leal Viana, brunoleal@recife.pe.gov.br
}

\begin{abstract}
Bowdichia virgilioides Kunth is a tree species of the family Fabaceae. The species is well adapted to dry and poor lands, being indicated for reforesting activities, being widely used on wood structures for civil construction, and also as a species with high medicinal potential. This study aimed to evaluate methods for overcoming dormancy of $B$. virgilioides seeds through different types of scarification and water submersion. To do so, four treatments and control were used: T1 - seeds with no treatment, T2 - mechanical scarification with \# 120 sandpaper; T3 - chemical scarification with concentrated sulfuric acid (98\%) for 10 minutes; T4 - submersion in hot water $\left(80^{\circ} \mathrm{C}\right)$ for 5 minutes; $T 5$ - submersion in water at room temperature (approximately $30^{\circ} \mathrm{C}$ ) for $48 \mathrm{~h}$. The experiment was conducted in a Completely Randomized Design (CRD) and the analyzed variables were: germination percentage $(\% \mathrm{G})$, average germination speed (VMG) and average germination time (TMG). Data was analyzed using the "GerminaQuant" software and results compared using Tukey's test at $5 \%$ probability. Germination percentage was higher for treatments 3 and 4, with the decreasing sequence: T3 - 82\%, T4 -64\%, $\mathrm{T} 2-9 \%, \mathrm{~T} 1-4 \%$ and $\mathrm{T} 5-2 \%$. Regarding average germination time, only $\mathrm{T} 2$ and $\mathrm{T} 1$ were statistically different from each other, T2 had the shortest time (10.33) and T1 the longest time (30.33). For VMG, T2 and T3 presented the best results, being statistically different from the other treatments, with 0.093 and 0.085 as respective results of T2 and T3. It could be concluded that treatments with immersion in sulfuric acid for 10 minutes (T3) and immersion in water at temperature of $80^{\circ} \mathrm{C}$ for five minutes (T4) are more efficient for improving germination percentage of B.virgilioides seeds, being the recommended methods for overcoming seed dormancy.
\end{abstract}

KEYWORDS: Bowdichia virgilioides; Sucupira; Dormancy; Forestry seeds; Atlantic Forest.

\section{SUPERAÇÃO DE DORMÊNCIA EM SEMENTES DE Bowdichia virgilioides Kunth}

RESUMO: Bowdichia virgilioides Kunth é uma espécie arbórea da família Fabaceae.Aespécie é bem adaptada a terrenos pobres e secos, sendo indicada para atividades de reflorestamento, além de ser amplamente utilizada em estruturas de madeira na construção civil, e amplo potencial medicinal. Sendo assim, este trabalho objetivou avaliar métodos para a superação da dormência de sementes de $B$. virgilioides submetidas a diferentes tratamentos de escarificação e imersão em água, visando recomendar um método eficiente para produção de mudas de $B$. virgilioides em viveiros. Para tal foram aplicados quatro tratamentos, além da testemunha (T1), a saber: T2 - escarificação mecânica com lixa $n^{0} 120$; T3- escarificação química com ácido sulfúrico concentrado a $98 \%$ por 10 minutos; T4- imersão em água a $80^{\circ} \mathrm{C}$ por 5 minutos; T5- imersão em água a temperatura ambiente por 48 horas. 0 experimento foi arranjado em delineamento inteiramente casualisado (DIC) e as variáveis analisadas foram: porcentagem de germinação (\%G), tempo médio de germinação (TMG) e velocidade média de germinação (VMG). Os dados foram analisados com o auxílio do programa GerminaQuant e as médias comparadas pelo teste de Tukey a $5 \%$ de probabilidade. A porcentagem de germinação, nos tratamentos 3 e 4 se sobressaíram $(P<0,05)$ aos demais. No tocante ao tempo médio de germinação, apenas T2 e T1 se diferenciaram estatisticamente, sendo o menor tempo observado para T2 $(10,33)$ e o maior para o T1 $(30,33)$. Quanto à VMG, o T2 e T3 obtiveram os melhores resultados, diferenciando-se estatisticamente dos demais tratamentos sendo 0,093 e 0,085 , os valores obtidos para os dois tratamentos, respectivamente. Conclui-se que os tratamentos com imersão em ácido sulfúrico por 10 minutos (T3) e imersão em água a $80^{\circ} \mathrm{C}$ por cinco minutos (T4) são mais eficientes quanto à porcentagem de germinação das sementes de sucupira-mirim, sendo o T4 mais eficiente também quanto à velocidade média de germinação, dessa forma, T4 é o tratamento mais eficiente, dentre os avaliados neste estudo, para a quebra de dormência dessas sementes.

PALAVRAS CHAVE: Sucupira; Imersão; Escarificação; Sementes florestais; Mata Atlântica. 


\section{INTRODUCTION}

Bowdichia virgilioides Kunth, popularly known as sucupira-preta, sucupira-mirim, or paricarana, is a tree species belonging to family Fabaceae, subfamily Faboideae. The species is native to Cerrado and Atlantic Forest, being classified by Oliveira et al. (2011) as late secondary with seeds of anemocoric dispersion.

The species has high-density wood, being widely used in civil construction, mainly for the construction of floors and finishes for doors and windows. It also adapts to dry and poor soils, being also used for the recovery of degraded areas or even in urban arborization (LORENZI, 1992). According to Leite et al. (2014), B. virgilioides presents notorious medicinal potential, being present in its composition caffeic and chlorogenic acids, substances that aid the activity of bactericides. Agra et al. (2013) investigated the healing power of substances present in sucupira bark and obtained results that indicated the high healing power of the species. Therefore, all these potentials of use and properties make this species interesting for the production of seedlings in forest nurseries.

Despite all the characteristics beneficial to man and environmental services that the species presents, the production of seedlings in large scale is difficult due to the presence of dormancy mechanism in its seeds. Seed dormancy is defined by Popinigis (1985) as an evolutionary mechanism for seeds in adverse climatic conditions, using as example winter cold in temperate regions and low water supply of arid climates. Baskin and Baskin (2004) characterize seed dormancy as germination incapacity, even in a favorable environment. This disability disappears as soon as the dormancy is broken.

According to Bewley (1997), there are two dormancy categories, embryonic dormancy, when dormancy is due to incompleteness and / or immaturity of the embryo development and the coat dormancy, which comprises mechanisms external to the embryo, being present in the outer sections or parts of the seed, forming one or more layers that make the penetration of light and water into the embryo difficult.

Sucupira-mirim seeds have on their surface a reddish, smooth, very rigid and waterproofing coat, possibly responsible for the presence of dormancy in the species, which normally has low germination rates when not submitted to pre-germination treatments. Albuquerque etal. (2007) obtained only $11 \%$ germination rate in untreated seeds. Andrade et al. (1997) also obtained very low values, close to $2.1 \%$ for untreated seeds. Associating the rates of previous studies and the classification systems of Bewley (1997), Baskin and Baskin (1998) and Baskin and Baskin (2004), it is believed that $B$. virgilioides seeds have physical coattype dormancy.

Fowler and Bianchetti (2000) recommend the use of three methods for overcoming seeds that present this type of dormancy: 1) chemical scarification, in which seeds are immersed in some corrosive material, usually an acid, for a certain period of time; 2 ) immersion in water, whether hot or at room temperature, also for a certain period of time. 3) Mechanical scarification using sandpaper or blade to submit seeds to abrasion, to thin or break the integument.

The present research had the aim of evaluating methods to overcome the dormancy of $B$. virgilioides seeds submitted to different scarification and immersion treatments in order to find and recommend an efficient method that leads to high germination percentage rates and reduces the germination time and production of $B$. virgilioides seedling in nurseries.

\section{MATERIAL AND METHODS}

The study was conducted at the Botanical Garden of Recife (JBR), in a greenhouse, between April 28 and July 28, 2016.

For this, 500 seeds were used, 25 seeds per replicate and 100 seeds per treatment. Diaspores were collected in January 2016, on the banks of BR232, in the district of Curado, Recife-PE, at coordinates $8^{\circ} 4^{\prime} 25.68$ "and $34^{\circ} 57^{\prime} 50.97^{\prime \prime}$ latitude and longitude, respectively.

The experiment was conducted in a completely randomized experimental design (CRD), with four replicates and five treatments: T1 - control (intact seeds); T2 - mechanical scarification on the opposite side of the hilum with \# 120 sandpaper; T3- chemical scarification with $98 \%$ concentrated sulfuric acid for 10 minutes; T4- immersion in water at $80^{\circ} \mathrm{C}$ for 5 minutes; T5- immersion in water at room temperature for 48 hours.

After the application of treatments, seeds were sown approximately one centimeter deep in polypropylene plastic trays of $25 \mathrm{~cm}$ in width, $40 \mathrm{~cm}$ in length and $8 \mathrm{~cm}$ in depth, duly filled with sand previously 
washed and sieved, being placed at room temperature. After sowing, manual irrigation was carried out with the aid of a watering can twice a day, in the morning and in the afternoon. The variables analyzed were: germination percentage ( $\% \mathrm{G})$, average germination time (TMG) and average germination speed (VMG).

Data were analyzed with the aid of the GerminaQuant software version 1.0, using the formulas:

$$
\% \mathrm{G}=(\mathrm{N} / \mathrm{T}) \times 100
$$

where $\mathrm{N}=$ Number of germinated seeds and $\mathrm{T}=$ Total seeds of the treatment.

$$
\mathrm{TMG}=(\Sigma \mathrm{niti}) / \Sigma \mathrm{ni})
$$

where $\mathrm{ni}=$ number of seeds germinated on a given day and $\mathrm{t} i=$ days after the beginning of the experiment and TMG measured in days.

$$
\text { VMG }=1 / T M G
$$

where VMG is measured in days ${ }^{-1}$.

Averages were compared by the Tukey test at $5 \%$ probability, with the aid of the program Sisvar 5.6 software.

\section{RESULTS AND DISCUSSION}

For variable $\% \mathrm{G}$, chemical scarification with $98 \%$ concentrated sulfuric acid for 10 minutes (T3) obtained $82 \%$ efficiency, immersion in water at $80^{\circ} \mathrm{C}$ for 5 minutes (T4), with 64\% efficiency, resulted in high indexes, when compared to control (T1), which obtained $4 \%$ of germinated seeds, according to Figure 1.

Figure 1: Germination percentage of Bowdichia virgilioides seeds submitted to different scarification and immersion treatments.

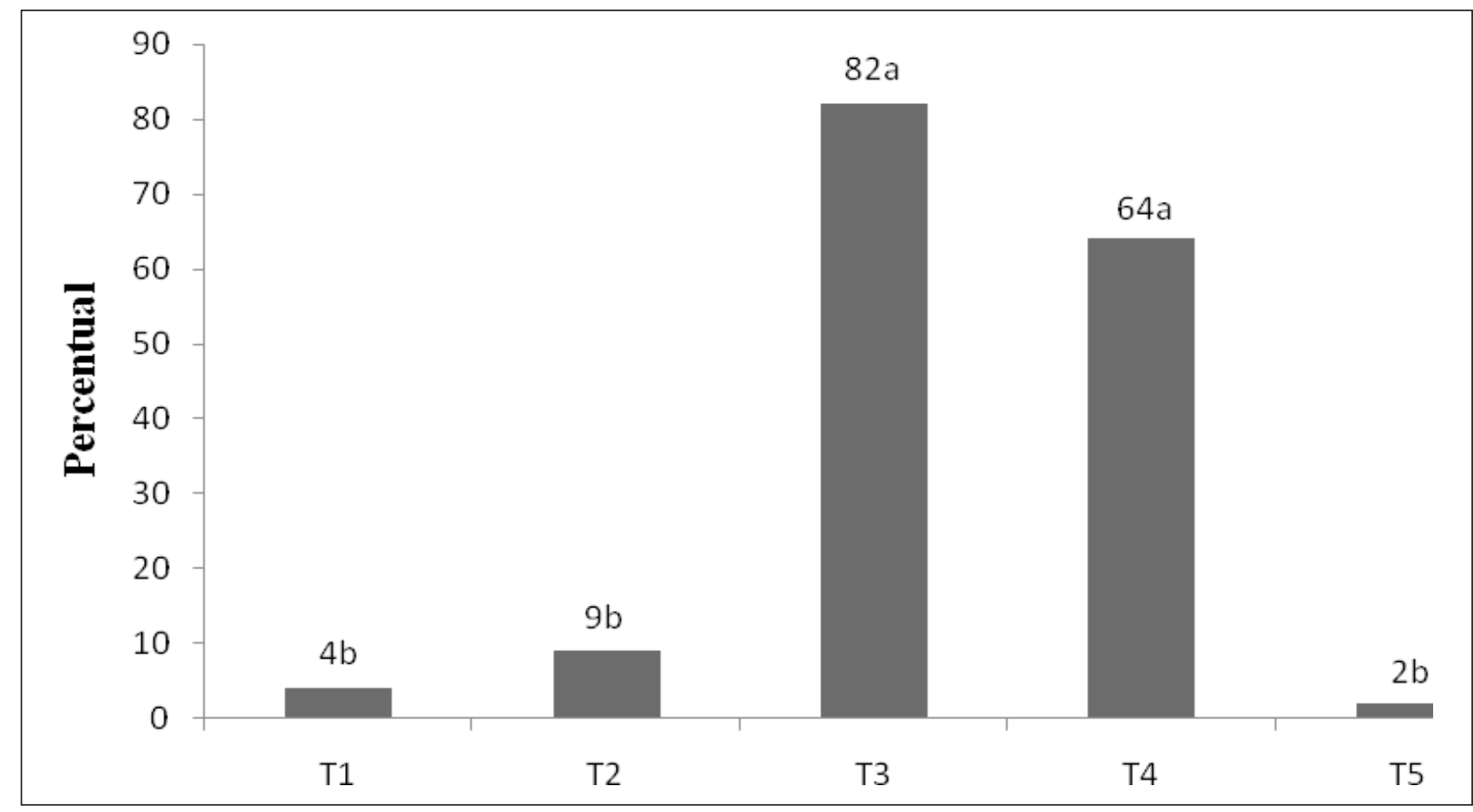

Tukey test at $5 \%$ probability. Variation Coefficient $=30.55 \%$.

In experiments with the same species, Andrade et al. (1997) used immersion in water at $100^{\circ} \mathrm{C}$ for different times (1, 2 and 3 minutes) and immersion in $98 \%$ concentrated sulfuric acid at different times ( 1,5 , 10, 15 and 20 minutes), as well as immersion in water at room temperature for 24 hours. The germination percentage of treatment with concentrated sulfuric acid for 10 minutes was similar to the present study, of $80.5 \%$ and $82 \%$, respectively. Immersion in water for prolonged periods, that is, for 24 and 48 hours did not cause improvement in the seed germination rates of sucupira-mirim.

Albuquerque et al. (2007), also with the same species, used treatments with immersion in sulfuric acid and water. Concentrated sulfuric acid was used at different times (4, 8 and $12 \mathrm{~min}$ ), in these, treatment with 8 minutes was the one that obtained the best result, and that more approached the results 
obtained in T3 of the present study, the results being equal to 77 and $82 \%$. Immersion was performed with water at $80^{\circ} \mathrm{C}$ for 5 and $10 \mathrm{~min}$, both times showing results similar to each other and to those of the present study, all being around $60 \%$. Albuquerque et al. (2007) used mechanical scarification as a way to overcome dormancy. However, unlike the present study, they obtained significant gains in $\% \mathrm{G}$, reaching $66 \%$, while in this study, value of $9 \%$ was obtained.

Smiderle and Sousa (2003), in a study with the same species, applied treatments with mechanical scarification with sandpaper for one minute and chemical treatment with concentrated sulfuric acid for 5 and 10 minutes. In mechanical scarification, results were higher than those obtained by Albuquerque et al. (2007) and markedly higher than those of the current study, with germination percentages of 79,66 and $9 \%$ successively.

Gonçalves et al. (2008) carried out a study analyzing germination percentage and speed of sucupira-preta, submitted the seeds to treatment with sulfuric acid for five minutes and then according to treatment, immersed scarified seeds in water at $30^{\circ} \mathrm{C}$ for different times, $12,24,36,48 \mathrm{~h}$, in addition to control. Seeds progressed regarding the germination percentage, as the immersion period increased, with maximum value equal to $82 \%$, a result similar to that obtained by immersion in sulfuric acid in the present study.

For VMG, mechanical scarification with sandpaper and immersion in concentrated sulfuric acid showed the highest average germination rates measured in days, of 0.093 and 0.085 days $^{-1}$ (Figure 2 ), followed by control (0.036), immersion in water at $80^{\circ} \mathrm{C}$ for 5 minutes $(0.035)$ and immersion in water at room temperature for 48 hours $(0.030)$. It was observed that, in addition to presenting the best germination rates, T3 greatly increased the average germination speed in relation to control treatment.

Figure 2: Average germination speed of Bowdichia virgilioides seeds submitted to different scarification and immersion treatments.

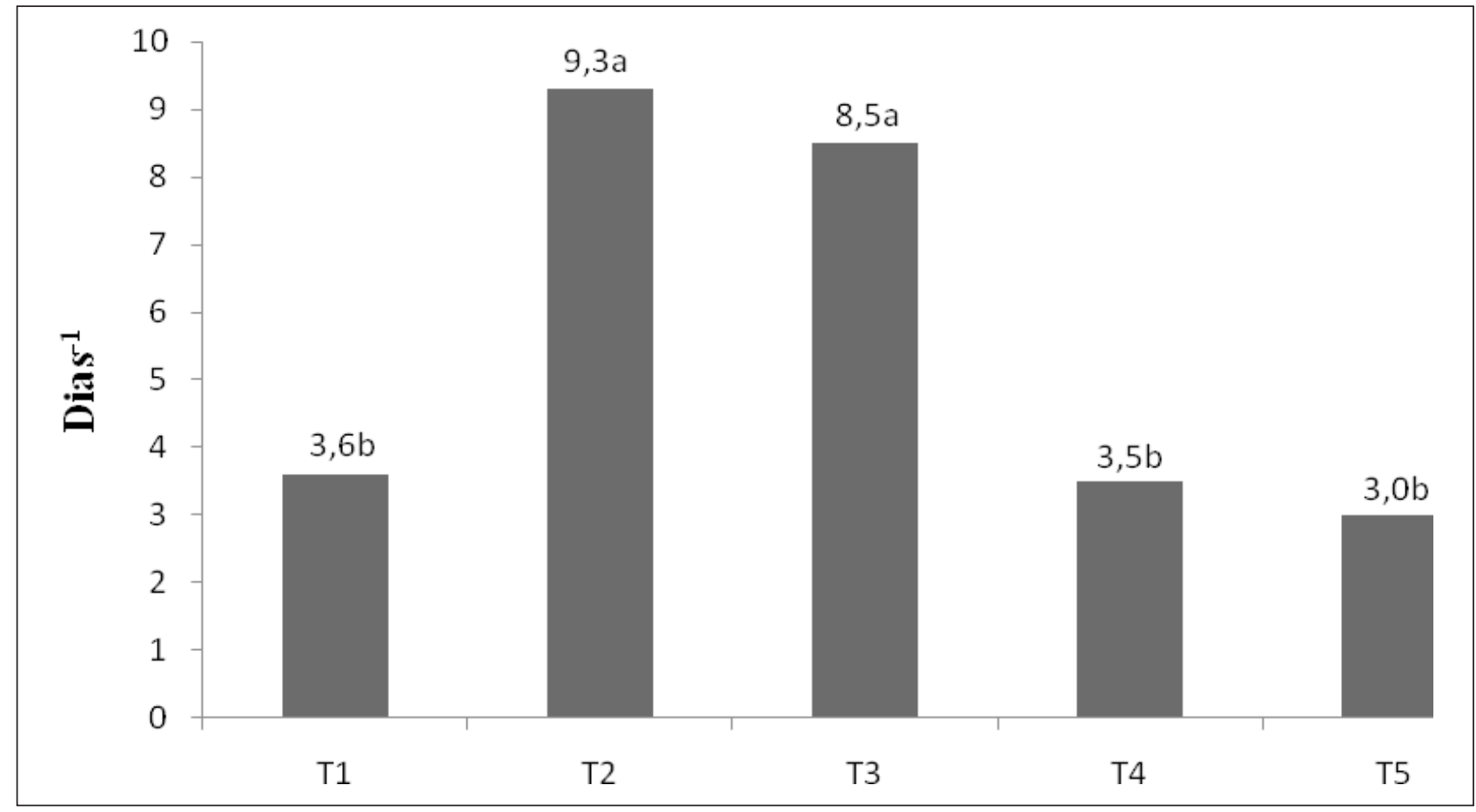

Tukey test at $5 \%$ probability. Variation Coefficient $=17.46 \%$.

Smiderle and Sousa (2003) evaluated the dormancy overcoming of $B$. virgilioides seeds and, as in this study, obtained better germination speed results for treatments with sandpaper and sulfuric acid, and these results were more than 10 times higher than those of controls, with results for control, mechanical scarification and immersion in acid, respectively: 0.9; 10.2; 10.3

Andrade et al. (1997) studied the same species and also obtained higher germination rates for $\mathrm{H}_{2} \mathrm{SO}_{4}$ 
treatments, in particular for treatments with 10 and $15 \mathrm{~min}$ immersion in acid. Water immersion treatment, similar to the present study, did not present significant improvement in the germination speed. Sequentially, the best results were: immersion in acid for $15 \mathrm{~min}$ (0.16), immersion in acid for $10 \mathrm{~min}$ (0.15), immersion in acid for 5 and $20 \mathrm{~min}$ (0.12). Immersion in water at room temperature for $24 \mathrm{~h}$ and control had 0.06 and 0.04 , respectively.
As for TMG, mechanical scarification stood out; however, it was statistically different only from control (Figure 3). T3 (chemical scarification with 98\% concentrated sulfuric acid for 10 minutes) presented result close to that of T2, of 10 and 11 days, respectively. Immersion in water for $48 \mathrm{~h}$ did not significantly improve the average germination time.

Figure 3: Average germination time (days) of Bowdichia virgilioides seeds submitted to different scarification and immersion treatments.

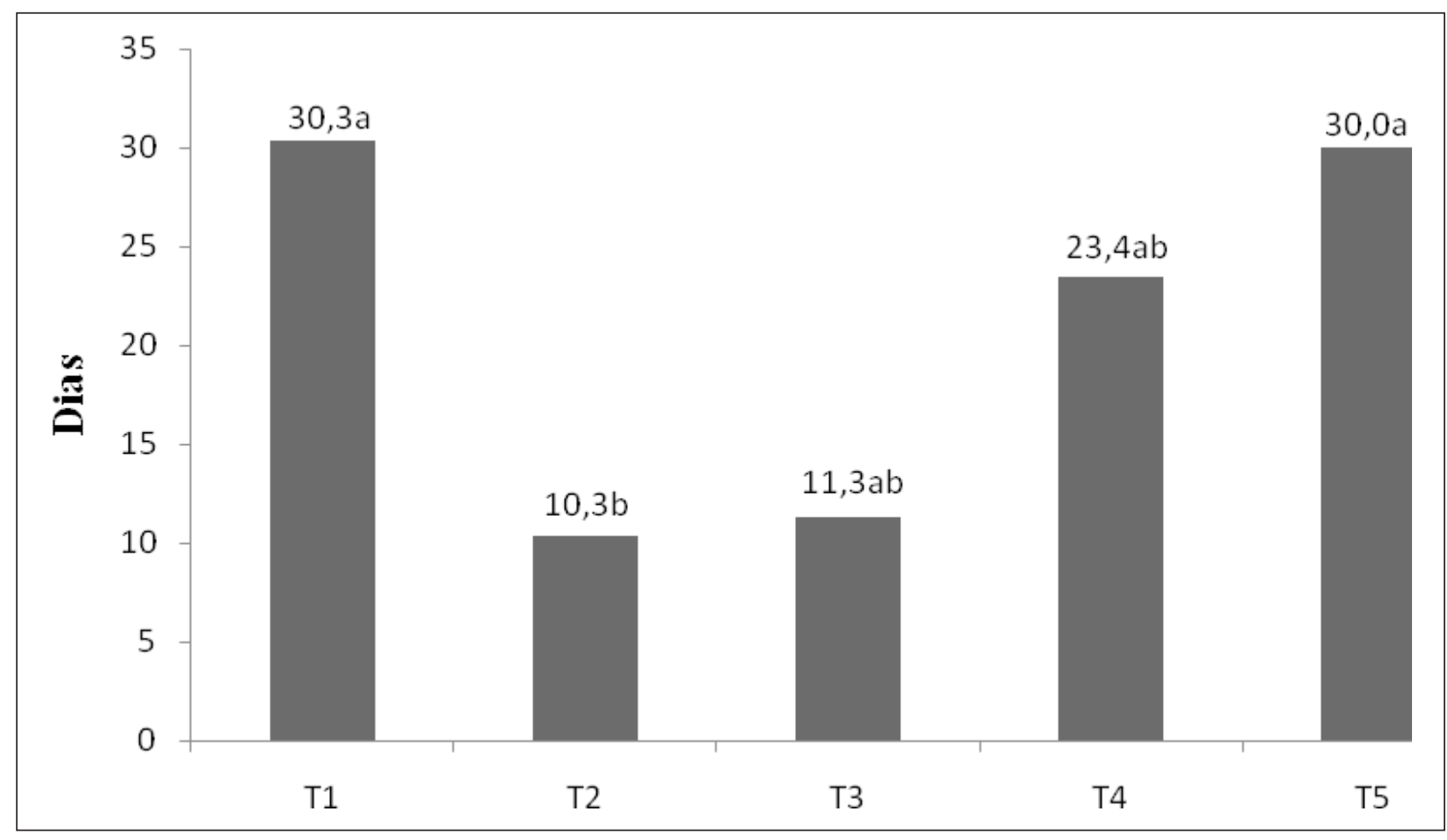

Tukey test at $5 \%$ probability. Variation Coefficient $=37.61 \%$

Treatment with concentrated sulfuric acid probably obtained the best results due to the time of acid application. Other authors used different times, and based on those of this study, a new immersion time was chosen, probably the time chosen was sufficient to soften or corrode the seed coat more efficiently than in Rosa-Magri and Meneghin (2014) and Albuquerque et al. (2007) and caused no damage to the embryo.

In the case of water treatments at $80^{\circ} \mathrm{C}$ and water at room temperature, the results may have been so different for some reasons. As the breakage of tegument dormancy consists in the cracking, softening or breaking of the tegument, at the first moment, temperature may have caused a thermal shock to seeds, causing the tegument to crack. For immersion for 48 hours there may be two cases: 1- water at room temperature could not penetrate in significant amounts in seeds. 2 - excessive immersion time of seeds may have caused the activation of the embryo, leading to death due to lack of oxygenation.

Similar situations were observed in a study by Rosa-Magri and Meneghin (2014), where treatments with immersion in water at 25 and $30^{\circ} \mathrm{C}$ for 24 hours were used, as well as immersion in water at $80^{\circ} \mathrm{C}$ for 3 hours. Treatments with immersion for 24 hours did not result in significant increase of the germination percentage. Treatment with immersion in water at $80^{\circ} \mathrm{C}$ for 3 hours resulted in death or non-activation of all embryos. According to results of this work and those obtained by Rosa-Magri and Meneghin (2014) and that of Smiderle and Sousa (2003), it could be inferred that temperature causes greater effect on seeds than immersion in water. 
Taking into account that physical dormancy breaks occur through cracking or softening of the waterproofing seed coat, the success or failure of methods must be linked to the form of application. It is believed that scarification with sandpaper \# 120 did not efficiently promote the entry of water into the seed; therefore, not obtaining the same yield as in the works of Albuquerque et al. (2007) or Smiderle and Sousa (2003), which may be due to the scarification time or to the intensity applied in the procedure.

Immersion in water at room temperature for 48 $\mathrm{h}$, without prior scarification, impaired the germination of $B$. virgilioides seeds, reducing the percentage to $2 \%$, in addition to reducing the average germination speed.

Immersion of $B$. virgilioides seeds in $98 \%$ concentrated sulfuric acid for 10 minutes is the most efficient method among those presented in this study to overcome dormancy and accelerate the germination process of these seeds.

Immersion in water at $80^{\circ} \mathrm{C}$ may be an alternative for overcoming dormancy in the species, considering that, although not resulting in such high germination percentages, it is a low-cost and easy-toapply method; however, the average germination time is considered to be more than double when compared to seeds treated with sulfuric acid.

\section{ACKNOWLEDGMENTS}

To FACEPE for the scholarship granted to IEL and for the financial support, and to the Botanical Garden of Recife for the opportunity to practice and develop research activities.

\section{REFERENCES}

Agra, I. K. R., Pires, L. L. S., Carvalho, P. S. M., SilvaFilho, E. A., Smaniotto, S., e Barreto, E. Evaluation of wound healing and antimicrobial properties of aqueous extract from Bowdichia virgilioides stem barks in mice. Anais da Academia Brasileira de Ciências, 2013, 85, 3 , 945-954.

Albuquerque, K. S., Guimarães, R. M., Almeida, Í. F. de, e Clemente, A. da C. S. Métodos para a superação da dormência em sementes de sucupira-preta (Bowdichia virgilioides Kunth.). Ciência e Agrotecnologia, 2007, 31, 6, 1716-1721.
Andrade, A. C. S., Loureiro, M. B., De Oliveira Souza, A. D., e Ramos, F. N. Quebra de dormência de sementes de sucupira-preta. Pesquisa Agropecuária Brasileira, 1997, 32, 5, 465-469.

Baskin, C.C; Baskin, J.M. Types of Seed Dormancy. In.Seeds: ecology, biogeography and evolution of dormancy and germination. Academic Press, San Diego. 666p, 1998.

Baskin, J. M; Baskin, C. C. A classification system for seed dormancy. Seed Science Research, 2004, 14, $16 p$.

Bewley, J. D. Seed Germination and Dormancy. The Plant Cell, 1997, 9, 1055-1066.

Fowler, J.; Bianchetti, A. Dormência em sementes florestais. Embrapa Florestas Documentos, 2000, 1-28.

Gonçalves, J. V. S., Albrecht, J. M. F., Soares, T. S., e Titon, M. Caracterização física e avaliação da préembebição na germinação de sementes de sucupirapreta (Bowdichia virgilioides Kunth). Cerne, 2008, 14, 4, 330-334.

Leite, L. H. I., Tintino, S. R., Figueredo, F. G., Oliveira, C. D. de M., de Oliveira, L., Siebra, A. L. de A., Kerntopf, M. R. Composição química e estudo da atividade antibacteriana de Bowdichia virgilioides Kunth (Sucupira) Fabaceae Papilonoidae. Boletin Latinoamericano Y Del Caribe de Plantas Medicinales Y Aromaticas, 2014, 13, 5, 477-487.

Lorenzi, H. Arvores Brasileiras: manual de identificação e cultivo de plantas arbóreas nativas do Brasil. Editora Plantarum: Nova Odessa, São Paulo, 1992; Volume 1. Número 1.368p.

Oliveira, L. S. B., Marangon, L. C., Feliciano, A. L. P., Lima, A. S., Cardoso, M. O., e Silva, V. F. Florística, classificação sucessional e síndromes de dispersão em um remanescente de Floresta Atlântica, MorenoPE. Revista Brasileira de Ciências Agrárias, 2011, 6, 3, 502-507.

Popinigis, F. Dormência. In. Fisiologia da semente. AGIPLAN: Brasília, Distrito Federal, 1985; Volume 1. Número 1.289p. 
Rosa-Magri, M.M., e Meneghin, S.P. Avaliação das Smiderle, O. J., e Sousa, R. C. P. Superação da características germinativas da espécie arbórea dormência em sementes de paricarana (Bowdichia sucupira-preta (Bowdichia virgilioides Kunth - virgilioides Kunth.). Revista Brasileira de Sementes, Fabaceae). Bioikos, 2014, 28, 1, 3-10. 2003, 25, 2, 48-52. 